\title{
Renin Angiotensin System and Coronavirus Disease 2019 (COVID-19): An updated review
}

Rolando S. Vela Vásquez

Correspondence: velarolando@gmail.com

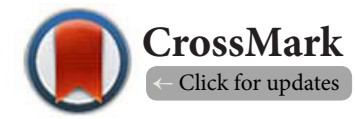

Department of Cardiology, Cajamarca Essalud Hospital, 939 Mario Urteaga Avenue, Cajamarca, Perú.

\begin{abstract}
Abnormal Renin-Angiotensin System (RAS) activation has a pivotal role in pathogenesis of cardiovascular or metabolic diseases, known risk factors for poor outcomes in COVID-19. An additional tissue RAS imbalance trough interaction of 'severe acute respiratory syndrome coronavirus 2' (SARS-CoV-2) with angiotensin-converting enzyme 2 (ACE-2) seems to play a role in pathogenesis of COVID-19. This interaction has raised some questions about safety of RAS-inhibitors use in COVID-19 patients. On the other hand, potential benefits of RAS-inhibitors use have been suggested. This article presents a brief updated review of renin-angiotensin system (RAS) focusing on interaction with SARS-CoV-2 infection, potential risks or benefits of RAS-inhibitors use, and RAS-related therapeutic targets in COVID-19.

Keywords: Coronavirus disease 2019, COVID-19, angiotensin-converting enzyme 2, renin-angiotensin system, renin-angiotensin system blockers
\end{abstract}

\section{Introduction}

In December 2019, a novel coronavirus capable of infecting and causing disease in human species emerged in Wuhan city (China) and spreads rapidly across the world [1]. As of July 19, 2020, a total of 14360451 confirmed cases and 603378 deaths had been reported in 188 countries/regions worldwide [2], and the numbers continue to rise.

The new coronavirus has been officially named "severe acute respiratory syndrome (SARS) coronavirus 2" or SARS-CoV-2, by similarity to coronavirus SARS-CoV, which caused an outbreak of SARS in 2003. The coronavirus disease caused by SARS-CoV-2 was named "coronavirus disease 2019" or COVID-19 [3].

COVID-19 has a broad clinical spectrum ranging from mild upper respiratory tract symptoms in most cases to severe pneumonia and acute respiratory distress syndrome (ARDS) with respiratory failure, the main cause of morbidity and mortality $[4,5]$. Hypertension and cardiovascular diseases, as other comorbidities, have been identified as risk factors for developing severe disease and increased mortality [4-7].

Recent knowledge that novel coronavirus SARS-CoV-2, like coronavirus SARS-CoV, uses angiotensin-conversing enzyme 2 (ACE-2) as receptor to entry into host cells [8,9], has rapidly pushed up concerns about safety of renin-angiotensin system inhibitors use, by potential ability to increase ACE-2 expression, hypothetically favouring virus entry and disease virulence in cardiovascular patients [10-13].

The purpose of this article is to summarize an updated review of renin-angiotensin system focusing on interaction with SARS-CoV-2 infection, potential risks or benefits of RAS inhibitors use, and RAS-related therapeutic targets in COVID-19. An electronic search was performed in Medline (PubMed interface) using the keywords: coronavirus, coronavirus disease 2019, COVID-19, SARS-CoV-2, angiotensin-converting enzyme 2, ACE2, renin-angiotensin system, renin-angiotensin system blockers, cardiovascular system, cardiovascular disease, and their various combinations, between 2019 and June 30, 2020. Additional articles were obtained of references in the selected articles.

\section{Review}

\section{Renin-Angiotensin System revisited}

The renin-angiotensin system has a central role in normal physiology regulating hydroelectrolytic balance and blood pressure. Also, RAS plays a critical role in pathogenesis and pathophysiology of cardiovascular disease [14-16]. In modern concept, RAS has two pathways that mutually influence each other: the classical and alternate pathways. Cardiovascular homeostasis results from the balance between these dual effects. Circulating RAS coexists with a local or tissue RAS [14,17-19]. 
Rolando Vela Vasquez, Cardiovascular System 2020,

http://www.hoajonline.com/journals/pdf/2052-4358-8-2.pdf

doi: $10.7243 / 2052-4358-8-2$

Classical RAS axis: ACE / Angiotensin II / AT1-receptor Major components of the classical axis include: angiotensinogen, renin, angiotensin I, angiotensin II and the angiotensinconverting enzyme (ACE). Angiotensin II is the principal effector of the classic axis $[14,17,18]$.

The substrate of the system is angiotensinogen, a protein synthesized and released into circulation from the liver. Angiotensinogen is converted to angiotensin I by renin, secreted by the juxtaglomerular apparatus of the kidney. Subsequently, angiotensin I is converted to angiotensin II by angiotensinconverting enzyme. ACE is expressed in high quantities on the surface of the vascular endothelial cells of pulmonary circulation. Beside of the lungs, ACE is expressed, to a lesser extent, in other tissues: kidney, intestine, placenta, choroid plexus and testicles $[14,17,18]$.

Angiotensin II is the most potent regulatory peptide of the classical axis exerting its biological effects through two cellular receptors: angiotensin type-1 (AT1) and angiotensin type-2 (AT2) receptors. Angiotensin II acts mainly through AT1 receptor. AT-1 receptor activation causes vasoconstriction, hypertrophy, inflammation, and apoptosis. AT-2 receptor activation results in vasodilation, as well as anti-inflammatory and antiproliferative effects. Angiotensin II also stimulates aldosterone secretion from the adrenal cortex, which participates in hydroelectrolytic and blood pressure homeostasis, but may also lead to pathological effects, mainly tissue fibrosis and oxidative stress [14-19].

Angiotensin II is metabolized in few minutes by angiotensinconverting enzyme 2 (ACE-2), which has a pivotal role in the alternate RAS axis $[17,20]$.

\section{Alternate or counter-regulatory RAS axis: ACE-2/ Angiotensin 1-7/Mas-receptor}

Components of this counter-regulatory axis include: angiotensin-converting enzyme 2, angiotensin 1-7 and its protooncogene Mas receptor $[17,18]$.

ACE-2 is a membrane bound protein that has an extracellular domain with catalytic activity against angiotensin I (producing angiotensin 1-9) and angiotensin II (producing angiotensin 1-7). The ACE-2 catalytic efficiency for AT-II is almost 400 times greater that for AT-I, so angiotensin 1-7 is the main product of ACE-2 activity $[17,18,21]$.

Angiotensin 1-7 can also be generated from angiotensin I. In a first step, ACE-2 hydrolyses AT-I to generate angiotensin $1-9$, which is subsequently hydrolysed by ACE to generate angiotensin 1-7 [17].

The physiological role of angiotensin 1-7, the main active product of the alternate axis, has not yet fully elucidated, but data suggests that plays a crucial role in counteracting the damaging effects of AT-II. Angiotensin 1-7 has been shown to be beneficial through its vasodilatory, antithrombotic and antiproliferative effects, mainly mediated by its interaction with Mas receptor and probably also with AT2 receptor $[14,17,22-24]$.
The catalytic domain of ACE- 2 shares $42 \%$ identity and $61 \%$ similarity to catalytic portion of ACE, but is not inhibited by classical ACE inhibitors (ACEls) $[23,25]$. The membrane-bound extracellular domain of ECA-2 can be cleaved by the metalloproteinase ADAM17, which release a soluble form of ACE-2 [17].

ACE- 2 is present in a wide variety of cells and tissues, with increased expression in vascular endothelial cells, lung, heart, and kidney. It has also been described in the gastrointestinal system, nervous system and testis $[17,20,22,24]$. In the lungs, ACE-2 was found in alveolar epithelial cells, mainly in type II pneumocytes [22,26].

In addition, ACE-2 has been identified as receptor for novel coronavirus SARS-CoV-2 [9].

\section{The SARS-CoV-2/RAS interaction}

SARS-CoV-2 is a spherical enveloped, positive-sense, singlestranded RNA betacoronavirus, characterized by presenting spicular crown-shaped projections. The SARS-CoV-2 genome shares about $80 \%$ identity with that of SARS-CoV and is almost $96 \%$ identical to a bat coronavirus $[\mathbf{2 7}, \mathbf{2 8}]$.

Coronavirus spike protein (S protein) facilitates binding and viral entry into target cells. $S$ protein is conformed of 2 subunits: $\mathrm{S} 1$ and $\mathrm{S} 2$ subunits. $\mathrm{S} 1$ subunit facilitates viral attachment to the cell surface receptor, but entry requires $S$ protein preprocessing (priming) by a protease to expose S2 subunit, which ultimately facilitates fusion of viral envelope with cell membrane, allowing virus entry. The novel coronavirus SARS-CoV-2, like SARS-CoV, uses ACE-2 as membrane receptor and employs the membrane protease TMPRSS2 for $S$ protein priming. $S$ protein priming by TMPRSS2 protease is essential for viral entry into host cells $[8,9,27,28]$.

The $S$ protein/ACE-2 interaction seems to plays an important role in the pathogenesis of lung injury, the main determinant of morbimortality in coronavirus SARS-CoV and SARS-CoV-2 infection. In experimental models, both SARS-CoV infection and isolated $S$ protein infusion produce a considerable downregulation of pulmonary ACE-2 expression, without affecting pulmonary ACE expression. This would modify tissue RAS balance, favouring deleterious angiotensin II effects on lung tissue [29].

\section{COVID-19 and Renin-angiotensin system inhibitors}

RAS activation is known to play a critical role in the pathogenesis of cardiovascular diseases. Therefore, trying to modulate pathogenic effects of AT-II, RAS inhibitors are the cornerstone of pharmacological intervention. Classical RAS inhibitors, angiotensin converting enzyme inhibitors (ACEls) and angiotensin type 1 receptor blockers (ARBs) have shown robust evidence of their beneficial effects on cardiovascular morbimortality [30-32]. Although classical RAS-inhibitors do not inhibit ACE-2 activity, have shown be able to increase tissue ACE- 2 expression in animals [33-36] and humans $[37,38]$. This effect has triggered concerns about a greater vulnerability to SARS-CoV-2 infection among cardiovascular patients receiving these agents 
$[10,13]$. However, other publications strongly recommend against withdrawal of RAS inhibitors and even postulate potential benefits of this drugs in current pandemic $[39,40]$.

\section{COVID-19: Evidence for potential benefits of RAS} inhibitors

Coronavirus S protein/ACE-2 interaction may decrease pulmonary ACE-2 expression [29], favouring AT-II activity and its deleterious effects: vasoconstriction, inflammation and apoptosis. A marked elevation in plasma AT-II levels has been observed in COVID-19 patients with lung involvement, showing a linear association with total viral load and severity of lung injury [41]. Mouse experimental models of ARDS showed that AT-II activity promotes disease pathogenesis and that ACE- 2 expression protects from lung injury [42]. Likewise, decreased lung ACE-2 activity facilitates neutrophil infiltration and a more severe inflammatory response in a model of lung injury [43].

SRA inhibitors could have potential benefits in COVID-19 through 2 synergic mechanisms: its ability to directly blunting AT-II deleterious effects and to increase tissue ACE-2 expression [33-38]. In experimental models, RAS inhibition has shown protective effects against coronavirus-induced [29] and chemical-induced [42] lung injury. Likewise, recombinant ACE2 administration had protective effects in animal models of viral lung injury $[44,45]$. Additionally, a positive modulation on RAS components was observed in ARDS patients treated with recombinant ACE-2 [46]. These findings suggest a potential beneficial effect of RAS inhibitors in coronavirus-associated pulmonary disease.

In a retrospective multicenter study including 1128 hospitalized COVID-19 patients with hypertension, inpatient use of ACEI/ARB was associated with lower risk of all-cause mortality compared with ACEI/ARB non-user (adjusted hazard ratio, $0.42(95 \% \mathrm{Cl}, 0.19-0.92)$, p:0.03). This study not have the power to detect if there was a differential effect between ACEI and ARB [47].

\section{COVID-19: Evidence for potential deleterious effects} of RAS inhibitors

Knowledge of SARS-CoV-2 / ACE-2 interaction has raised questions about safety of RAS-inhibitors in COVID-19 patients. So far, the only argument put forward to support a hypothetical higher vulnerability to COVID-19 in RAS inhibitors users has been the ability of these agents to increase ACE-2 expression, which also acts as receptor for SARS-CoV-2 [10-13]. However, so far there is no evidence that this effect facilitates viral entry or increases disease virulence $[39,40,48]$. In vitro, only one of seven ACE-2 expressing cell lines was susceptible to coronavirus SARS-CoV infection, despite this cell line had an intermediate ACE-2 expression compared to each other, suggesting that ACE-2 by itself is insufficient to explain the coronavirus infectivity [49].

Several retrospective analyses have been published regarding the safety use of these drugs on COVID-19 patients. Taken together, provide convincing evidence that RAS inhibitors use is not associated with an increase in the likelihood of positive test for SARS-CoV-2 or in the risk of severe COVID-19 [50-53]. Even if ACEI/ARBs do upregulate ACE2 receptors, the absence of upregulation of TMPRSS2 may obviate enhanced viral entry into cells [54]. These findings support current professional society guidelines recommendations to no discontinue of ACEI/ ARB medications in the setting of COVID-19 pandemic [55].

\section{COVID-19 and Cardiovascular Disease: A risk beyond} of RAS inhibitors use

In COVID-19 patients, hypertension and cardiovascular disease have been identified as risk factors for adverse outcomes, without mention about how many patients were taking RAS inhibitors or any other medication [4-7]. Therefore, it is possible that a common condition beyond SRA inhibitors use is shared by these high-risk patients.

Abnormal RAS activation with increased AT-II activity plays a major role in pathogenesis and pathophysiology of hypertension, heart failure or ischemic heart disease $[15,16]$. On the other hand, AT-II by itself is capable to down-regulate tissue ACE-2 expression, attenuating the counter-regulatory response of tissue RAS alternate axis $[\mathbf{5 6 , 5 7 ]}$. Thus, common pathophysiological status in hypertension and cardiovascular diseases may be characterized by increased AT-II activity (classical RAS axis) and decreased tissue ACE-2 expression (alternate RAS axis).

The chronic and progressive nature of cardiovascular disease, despite optimal pharmacological RAS modulation, indicates that normal balance is never reached. In other words, despite optimal treatment, cardiovascular patients are never comparable to healthy population in relation to RAS homeostasis. Interestingly, abnormal RAS activation is shared by other conditions such as aging, obesity and diabetes mellitus that are also considered risk factors for poor outcomes in COVID-19 [58-61]. Besides, pulmonary ACE-2 expression is further reduced by SARS-coronavirus infection, producing an additional tissue RAS imbalance and yielding lung injury in these patients [29].

RAS imbalance with net RAS activation, rather than RAS inhibitors use or any treatment received could be the common risk condition in these patients, rendering them more prone to poor outcomes in current pandemic. Thus, potential benefits of RAS inhibitors are reinforced and a therapeutic opportunity for this high-risk group is raised $[55,61]$.

Finally, RAS inhibitors have proven benefits in cardiovascular diseases, and its withdrawal can precipitate serious complications or generate challenging difficulties in management among these high-risk patients [62-65]. Classical RAS inhibitors (ACEIs/ARBs) should be continuing in patients with known or suspected COVID-19 according to scientific societies' guidelines [55].

COVID-19 and RAS: Potential therapeutic targets Unfortunately, no vaccine or specific drug has yet approved 
Rolando Vela Vasquez, Cardiovascular System 2020,

http://www.hoajonline.com/journals/pdf/2052-4358-8-2.pdf

doi: $10.7243 / 2052-4358-8-2$

to treat COVID-19. Some potential RAS-related options are postulated:

-Delivering soluble forms of ACE-2: Soluble ACE-2 would serve as a decoy to virus preventing virus attachment to host cells. Additionally, soluble ACE-2 by itself can protect against lung injury by restoring pulmonary RAS balance. A pilot trial using recombinant human ACE-2 (APN01) in patients with severe COVID-19 has recently been started (Clinicaltrials.gov identifier: NCT04287686) $[40,66]$.

-Blocking ACE-2 receptor: Would prevent SARS-CoV-2 binding to host cells. Ideally, counter-regulatory ECA-2 activity should not be affected.

-Inhibition of membrane protease TMPRSS2 activity: Priming of coronavirus $\mathrm{S}$ proteins by TMPRSS2 protease is essential for viral entry into host cells. The serine protease inhibitor camostat mesylate, approved to treat unrelated diseases, has been shown to block TMPRSS2 activity [66].

-Modulation of tissue RAS activity: Based on the pathophysiology of RAS/SARS-CoV-2 interaction, RAS modulation may have a potential role in the management of patients with pulmonary affectation by COVID-19. Paired trials of losartan as a treatment for Covid-19 are being conducted among patients who have not previously received treatment with a RAAS inhibitor and are either hospitalized (ClinicalTrials.gov identifier: NCT04312009) or not hospitalized (ClinicalTrials.gov identifier: NCT04311177) [40,55]. Epidemiological studies are also needed to investigate clinical differences and outcomes between cardiovascular patients with COVID-19 treated and those not treated with classical RAS inhibitors.

\section{Conclusions}

Renin-angiotensin system has a pivotal role in normal physiology and pathogenesis of cardiovascular disease through dynamic balance between classical (angiotensin II mediated) and alternate (angiotensin 1-7 mediated) pathways. Angiotensin II promotes vasoconstrictive, proinflammatory and prothrombotic effects whereas angiotensin 1-7 has vasodilatory, anti-inflammatory and antithrombotic effects. RAS also seems to play a role in pathogenesis and pathophysiology of COVID-19. SARS-CoV-2 uses ACE-2 as receptor for entry into target cells and this interaction may downregulate tissue ACE- 2 expression, favouring deleterious AT-II activity in lungs. Although RAS-inhibitors may increase ACE-2 expression, so far there is no data supporting that this effect facilities viral entry or increases disease virulence. Based on current knowledge, there is no reason to withdrawal of RAS inhibitors in these patients. RAS imbalance with net RAS activation in older individuals or those with hypertension, metabolic or cardiovascular diseases could be the common risk condition that renders them more prone to poor outcomes in current pandemic.Thus, RAS modulation seems to have a potential role in the management of COVID-19. Overall, current data support potential beneficial effects of ACEI/ARB therapy in selected COVID-19 patients. Planned clinical trials are being conducted and will provide additional insight.

\section{Competing interests}

The author declares that he has no competing interests.

\section{Acknowledgments}

To my brother Victor for his inspirational battle against COVID-19.

Publication history

Editor: Xupei Huang, Florida Atlantic University, USA.

Received: 01-Aug-2020 Revised: 15-Oct-2020

Accepted: 29-Oct-2020 Published: 05-Nov-2020

\section{References}

1. Wu F, Zhao S, Yu B, Chen YM, Wang W, Song ZG, et al. A new coronavirus associated with human respiratory disease in China. Nature 2020; 579 : 265-269. DOI: 10.1038/s41586-020-2008-3

2. Dong $E$, Du H, Gardner L. An interactive web-based dashboard to track COVID-19 in real time. Lancet Infect Dis 2020. https://coronavirus.jhu. edu/map.html (July 19, 2020).

3. Wu Y, Ho W, Huang $\mathrm{Y}$, et al. SARS-CoV-2 is an appropiate name for the new coronavirus. Lancet 2020; 395: 949-950: DOI: 10.1016/S01406736(20)30557-2

4. Wu Z, Mcgoogan JM. Characteristics of and Important Lessons From the Coronavirus Disease 2019 (COVID-19) Outbreak in China Summary of a Report of 72314 Cases From the Chinese Center for Disease Control and Prevention. JAMA 2020; 323(13): 1239-1242. DOI: doi:10.1001/ jama.2020.2648

5. Guan WJ, Ni ZY, Hu Y, Liang WH, Ou CQ, He JX, Liu L, Shan H, Lei CL, Hui DSC, Du B, Li LJ, Zeng G, Yuen KY, Chen RC, Tang CL, Wang T, Chen PY, Xiang J, Li SY, Wang JL, Liang ZJ, Peng YX, Wei L, Liu Y, Hu YH, Peng P, Wang JM, Liu JY, Chen Z, Li G, Zheng ZJ, Qiu SQ, Luo J, Ye CJ, Zhu SY, Zhong NS; China Medical Treatment Expert Group for Covid-19. Clinical characteristics of coronavirus disease 2019 in China. N Engl J Med 2020. Epub ahead of print, March 6. DOI: 10.156/NEJMoa2002032

6. Zhou F et al. Clinical course and risk factors for mortality of adult inpatients with COVID-19 in Wuhan, China: a retrospective cohort study. Lancet 2020; 395: 1054-62. DOI: 10.1016/S0140-6736(20)30566-3

7. Yang J, Zheng Y, Gou X, et al. Prevalence of comorbidities in the novel Wuhan coronavirus (COVID-19) infection: a systematic review and meta-analysis. Int J Infect Dis 2020. Epub ahead of print, March 12. DOI: 10.1016/j.ijid.2020.03.017

8. Li W, Moore MJ, Vasilieva N, Sui J, Wong SK, Berne MA, Somasundaran M, Sullivan JL, Luzuriaga K, Greenough TC, Choe H, Farzan M. Angiotensinconverting enzyme 2 is a functional receptor for the SARS coronavirus. Nature 2003; 426:450-454. DOI: 10.1038/nature02145

9. Hoffmann M, Kleine-Weber $\mathrm{H}$, Schroeder S, Krüger $\mathrm{N}$, Herrler T, Erichsen S, Schiergens TS, Herrler G, Wu NH, Nitsche A, Müller MA, Drosten C, Pöhlmann S. SARS-CoV-2 cell entry depends on ACE2 and TMPRSS2 and is blocked by a clinically proven protease inhibitor. Cell 2020; 181(2): 271280. DOI: 10.1016/j.cell.2020.02.052

10. Sommerstein R, Grani C. Preventing a COVID-19 pandemic: ACE inhibitors as a potential risk factor for fatal COVID-19. BMJ 2020; 368: m810. DOI: 10.1136/bmj.m810

11. Fang L, Karakiulakis G, Roth M. Are patients with hypertension and diabetes mellitus at increased risk for COVID-19 infection? Lancet Respir Med 2020 March 11 (Epub ahead of print).

12. Esler M, Esler D. Can angiotensin receptor-blocking drugs perhaps be harmful in the COVID-19 pandemic? J Hypertens 2020 March 11 (Epub ahead of print).

13. Diaz JH. Hypothesis: angiotensin-converting enzyme inhibitors and angiotensin receptor blockers may increase the risk of severe COVID-19. J Travel Med 2020 March 18 (Epub ahead of print).

14. Farag E, Maheshwari K, Morgan J, et al. Un update of the role of renin angiotensin in cardiovascular homeostasis. Anest Analg. 2015; 120(2): 
Rolando Vela Vasquez, Cardiovascular System 2020,

\section{5-292. DOI: 10.1213/ANE.0000000000000528}

15. Ferrario CM. Role of Angiotensin II in Cardiovascular Disease Therapeutic implications of more than a century of research. J Renin Angiotensin Aldosterone Syst 2006; 7(1):3-14. DOI: 10.3317/ jraas.2006.003

16. Forrester SJ, Booz GW, Sigmund CD, Coffman TF, Kawait T, Rizzo V, Scalia R, Eguchi S. Angiotensin II signal transduction: an update on mechanism of physiology and pathophysiology. Physiol Rev 2018; 98: 1627-1738. DOI: 10.1152/physrev.00038.2017

17. Jiang $F$, Yang J, Zhang $Y$, et al. Angiotensin-converting enzyme 2 and angiotensin 1-7: novel therapeutic targets. Nat. Rev. Cardiol. 2014; 11: 413-426. DOI:10.1038/nrcardio.2014.59

18. Ocaranza MP, Riquelme JA, Garcia L, et al. Counter-regulatory reninangiotensin system in cardiovascular disease. Nat Rev Cardiol 2020; 17 : 116-129. DOI: 10.1038/s41569-019-0244-8

19. Nehme A, Zouein FA, Zayeri ZD, Zibara K. An Update on the Tissue Renin Angiotensin System and Its Role in Physiology and Pathology. J Cardiovasc Dev Dis 2019; 6(2): 14. DOI: 10.3390/jcdd6020014

20. Zisman LS. ACE and ACE2: a tale of two enzymes. Eur Heart J. 2005; 26(4): 322-324. doi:10.1093/eurheartj/ehi043

21. Iwai $M$, Horiuchi $M$. Devil and angel in the renin-angiotensin system: ACE-angiotensin II-AT, receptor axis vs. ACE2-angiotensin-(1-7)Mas receptor axis. Hypertens Res 2009; 32: 533-536. DOI: 10.1038/ hr.2009.74

22. Bader, M. ACE2, angiotensin(1-7), and Mas: the other side of the coin. Pflugers Arch. 2013; 465(1): 79-85. DOI: 10.1007/s00424-012-1120-0

23. Ferrario CM. Angiotensin-converting enzyme 2 and angiotensin-(1-7): an evolving story in cardiovascular regulation. Hypertension 2006; 47(3): 515-521. DOI: 10.1161/01.HYP.0000196268.08909.fb

24. Fyhrquist F, Saijonmaa O. Renin angiotensin system revisited. J Intern Med 2008; 264: 224-236. doi: 10.1111/j.1365-2796.2008.01981.x

25. Tikellis C, Thomas MC. Angiotensin-converting enzyme 2 (ACE 2 ) is a key modulator of the renin angiotensin system in health and disease. Int J Pept 2012; DOI: 10.1155/2012/256294

26. Hamming I, Timens W, Bulthuis MLC, Lely AT, Navis GJ, van Goor H. Tissue distribution of ACE2 protein, the functional receptor for SARS coronavirus: a first step in understanding SARS pathogenesis. J Pathol 2004; 203: 631-7. DOI: 10.1002/path.1570

27. Yang R, Zhang Y, Li Y, Xia L, Guo Y, Zhou Q. Structural basis for the recognition of SARS-CoV-2 by full-length human ACE2. Science 2020; 367: 1444-1448. DOI: 10.1126/science.abb2762

28. Zhou M, Zhang X, Qu J. Coronavirus disease 2019 (2019): a clinical update. Front Med 2020. Epub ahead of print, Apr 2. DOI: 10.1007/ s11684-020-0767-8

29. Kuba K, Imai Y, Rao S, Gao H, Guo F, Guan B, Huan Y, Yang P, Zhang Y, Deng W, Bao L, Zhang B, Liu G, Wang Z, Chappell M, Liu Y, Zheng D, Leibbrandt A, Wada T, Slutsky AS, Liu D, Qin C, Jiang C, Penninger JM. A crucial role of angiotensin converting enzyme 2 (ACE2) in SARS coronavirus-induced lung injury. Nat Med 2005; 11:875-879. DOI:10.1038/nm1267

30. Ponikowski P, Voors AA, Anker SD, Bueno H, Cleland JGF, Coats AJS, Falk V, Gonzalez-Juanatey JR, Harjola VP, Jankowska EA, Jessup M, Linde C, Nihoyannopoulos P, Parissis JT, Pieske B, Riley JP, Rosano GMC, Ruilope LM, Ruschitzka F, Rutten FH, van der Meer P; ESC Scientific Document Group. 2016 ESC Guidelines for the diagnosis and treatment of acute and chronic heart failure: the Task Force for the diagnosis and treatment of acute and chronic heart failure of the European Society of Cardiology (ESC)Developed with the special contribution of the Heart Failure Association (HFA) of the ESC. Eur Heart J 2016; 37:2129-2200. DOI: 10.1093/eurheartj/ehw128

31. Williams B, Mancia G, Spiering W, Agabiti Rosei E, Azizi M, Burnier M, Clement DL, Coca A, de Simone G, Dominiczak A, Kahan T, Mahfoud F, Redon J, Ruilope L, Zanchetti A, Kerins M, Kjeldsen SE, Kreutz R, Laurent S, Lip GYH, McManus R, Narkiewicz K, Ruschitzka F, Schmieder RE, Shlyakhto E, Tsioufis C, Aboyans V, Desormais I; ESC Scientific Document Group. 2018 ESC/ESH Guidelines for the management of arterial hypertension. Eur Heart J 2018; 39:3021-3104.DOI: 10.1093/eurheartj/ ehy339
32. Ibanez B, James S, Agewall S, Antunes MJ, Bucciarelli-Ducci C, Bueno H, Caforio ALP, Crea F, Goudevenos JA, Halvorsen S, Hindricks G, Kastrati A, Lenzen MJ, Prescott E, Roffi M, Valgimigli M, Varenhorst C, Vranckx P, Widimsky P; ESC Scientific Document Group. 2017 ESC Guidelines for the management of acute myocardial infarction in patients presenting with ST-segment elevation: the Task Force for the management of acute myocardial infarction in patients presenting with ST-segment elevation of the European Society of Cardiology (ESC). Eur Heart J 2018; 39 (2):119177. DOI: 10.1093/eurheartj/ehx393

33. Ferrario CM, Jessup J, Chappell MC, Averill DB, Brosnihan KB, Tallant EA, Diz DI, Gallagher PE. Effect of angiotensin-converting enzyme inhibition and angiotensin II receptor blockers on cardiac angiotensin-converting enzyme 2. Circulation 2005;111:2605-2610. DOI: DOI: 10.1161/ CIRCULATIONAHA.104.510461

34. Ishiyama Y, Gallagher PE, Averill DB, Tallant EA, Brosnihan KB, Ferrario $\mathrm{CM}$. Upregulation of angiotensin-converting enzyme 2 after myocardial infarction by blockade of angiotensin II receptors. Hypertension 2004; 43 : 970-6.DOI: 10.1161/01.HYP.0000124667.34652.1a

35. Ferrario CM, et al. Effects of renin-angiotensin system blockade on rena angiotensin-(1-7) forming enzymes and receptors. Kidney International 2005; 68: 2189-2196. DOI: 10.1111/j.1523-1755.2005.00675.x

36. Soler MJ, Ye M, Wysocki J, William J, Lloveras J, Batlle D. Localization of ACE2 in the renal vasculature: amplification by angiotensin II type 1 receptor blockade using telmisartan. Am J Physiol Renal Physiol 2009; 296: F398-F405. DOI: DOI: 10.1152/ajprenal.90488.2008

37. Vuille-dit-Bille RN, Camargo SM, Emmenegger L, et al. Human intestine luminal ACE2 and amino acid transporter expression increased by ACEinhibitors. Amino Acids 2015; 47(4): 693-705.doi: 10.1007/s00726-0141889-6

38. Furuhashi M, Moniwa N, Mita T, et al. Urinary angiotensinconverting enzyme 2 in hypertensive patients may be increased by olmesartan, an angiotensin II receptor blocker. Am J Hypertens 2015; 28(1): 15-21.doi: 10.1093/ajh/hpu086

39. Kuster GM, et al. SARS-CoV-2: should inhibitors of the renin angiotensin system be withdrawn in patients with COVID-19?. European Heart Journal 2020. Epub ahead of print, Mach 18, 2020. DOI:10.1093/ eurheartj/ehaa235

40. Vaduganathan M, Vardeny O, Michel T, McMurray JJV, Pfeffer MA, Solomon SD. Renin-Angiotensin-Aldosteron System Inhibitors in Patients with covid-19. NEJM 2020. Epub ahead of print, March 30. DOI: 10.1056/ NEJMsr2005760

41. Liu Y, Yang Y, Zhang C, et al. Clinical and biochemical indexes from 2019nCoV infected patients linked to viral loads and lung injury. Sci China Life Sci 2020; 63: 364-74.doi: 10.1007/s11427-020-1643-8

42. Imai Y, Kuba K, Rao S, Huan Y, Guo F, Guan B, Yang P, Sarao R, Wada T, Leong-Poi $\mathrm{H}$, et al. Angiotensin-converting enzyme 2 protects from severe acute lung failure. Nature 2005; 436: 112-116.DOI: 10.1038/ nature03712

43. Sodhi CP, Wohlford-Lenane C, Yamaguchi Y, et al. Attenuation of pulmonary ACE2 activity impairs inactivation of des-Arg9 bradykinin/ BKB1R axis and facilitates LPS-induced neutrophil infiltration. Am J Physiol Lung Cell Mol Physiol 2018; 314: L17-L31.doi.org/10.1152/ ajplung.00498.2016

44. Zou Z, Yan Y, Shu Y, et al. Angiotensin-converting enzyme 2 protects from lethal avian influenza A H5N1 infections. Nat Commun 2014; 5: 3594.doi: $10.1038 /$ ncomms4594.

45. Gu H, Xie Z, Li T, et al. Angiotensin-converting enzyme 2 inhibits lung injury induced by respiratory syncytial virus. Sci Rep 2016; 6: 19840. doi: 10.1038/srep19840

46. Khan A, Benthin C, Zeno B, et al. A pilot clinical trial of recombinant human angiotensin-converting enzyme 2 in acute respiratory distress syndrome. Crit Care 2017; 21: 234.doi: 10.1186/s13054-017-1823-x.

47. Zhang $P$, Zhu L, Cai J, et al. Association of inpatient use of angiotensin converting enzyme inhibitors and angiotensin II receptor blockers with mortality among patients with hypertension hospitalized with COVID-19. Circulation Research 2020; 126: 1671-81. DOI: 10.1161/ CIRCRESAHA.120.317134. 
Rolando Vela Vasquez, Cardiovascular System 2020,

http://www.hoajonline.com/journals/pdf/2052-4358-8-2.pdf

doi: $10.7243 / 2052-4358-8-2$

48. Jan Danser AH, Epstein M, Batlle D. Renin-Angiotensin System Blockers and the COVID-19 Pandemic. At Present There Is No Evidence to Abandon Renin-Angiotensin System Blockers. Hypertension 2020; 75:0000. DOI: 10.1161/HYPERTENSIONAHA.120.15082.

49. Chan PK, To KF, Lo AW, Cheung JL, Chu I, Au FW, Tong JH, Tam JS, Sung JJ, $\mathrm{Ng}$ HK. Persistent infection of SARS coronavirus in colonic cells in vitro. J Med Virol 2004; 74: 1-7. DOI: 10.1002/jmv.20138.

50. Fosb $\varnothing \mid \mathrm{EL}$, Butt JH, $\varnothing$ stergaard L, et al. Association of angiotensinconverting enzyme inhibitor or angiotensin receptor blocker use with COVID-19 diagnosis and mortality. JAMA. Published online June 19, 2020 doi:10.1001/jama.2020.11301

51. Mehta N, Kalra A, Nowacki AS, et al. Association of use of angiotensinconverting enzyme inhibitors and angiotensin II receptor blockers with testing positive for coronavirus disease 2019 (COVID-19). JAMA Cardiol. Published online May 5, 2020. doi:10.1001/jamacardio.2020.1855

52. Mancia G, Rea F, Ludergnani M, Apolone G, Corrao G. Reninangiotensin-aldosterone blockers and the risk of COVID-19. N Eng/ J Med. Published online May 1, 2020. doi:10.1056/NEJMoa2006923

53. Reynolds HR, Adhikari S, Pulgarin C, et al. Renin-angiotensinaldosterone inhibitors and risk of COVID-19. N Engl J Med. Published online May 1, 2020. doi:10.1056/NEJMoa2008975

54. Curfman G. Renin-Angiotensin-Aldosterone Inhibitors and Susceptibility to and Severity of COVID-19. JAMA 2020; 324(2): 177-8. doi:10.1001/ jama.2020.11401

55. Bavishi C, Maddox TM, Messerli FH. Coronavirus Disease 2019 (COVID-19) Infection and Renin Angiotensin System Blockers. JAMA Cardiol 2020; [Epub ahead of print, Apr 3]. DOI:10.1001/ jamacardio.2020.1282

56. Koka V, Huang XR, Chung AC, Wang W, Truong LD, Lan HY. Angiotensin II Up-Regulates Angiotensin I Converting Enzyme (ACE), but DownRegulates ACE2 via the AT1-ERK/p38 MAP Kinase Pathway. Am J Pathol 2008, 172(5):1174-1183. DOI: 10.2353/ajpath.2008.070762

57. Deshotels MR, Xia H, Sriramula S, Lazartigues E, Filipeanu CM. Angiotensin II Mediates Angiotensin Converting Enzyme Type 2 Internalization and Degradation Through an Angiotensin II Type I Receptor-Dependent Mechanism. Hypertension 2014; 64 (6):1368-1375. DOI: 10.1161/HYPERTENSIONAHA.114.0374

58. Lim HS et al. Diabetes Mellitus, the Renin-Angiotensin-Aldosterone System, and the Heart. Arch Intern Med. 2004; 164: 1737-48. DOI: 10.1001/archinte.164.16.1737

59. Schmieder RE et al. Renin-angiotensin system and cardiovascular risk. Lancet 2007; 369: 1208-19.DOI: 10.1016/S0140-6736(07)60242-6

60 . Theti $T$ et al. The link between the renin-angiotensin-aldosterone system and renal injury in obesity and the metabolic síndrome. Curr Hypertens Rep 2012. 14(2): 160-169. doi: 10.1007/s11906-012-0245-z

61. AlGhatrif M, Cingolani O, Lakatta EG. The Dilemma of Coronavirus Disease 2019, Aging, and Cardiovascular Disease: Insights From Cardiovascular Aging Science. JAMA Cardiol. 2020; Epub ahead of print, April 03, 2020. doi:10.1001/jamacardio.2020.1329

62. Pflugfelder PW, Baird MG, Tonkon MJ, DiBianco R, Pitt B. Clinical consequences of angiotensin-converting enzyme inhibitor withdrawal in chronic heart failure: a double-blind, placebo controlled study of quinapril. J Am Coll Cardiol 1993; 22: 1557-63.DOI: 10.1016/07351097(93)90578-0

63. Halliday BP, Wassall R, Lota AS, et al. Withdrawal of pharmacological treatment for heart failure in patients with recovered dilated cardiomyopathy (TRED-HF): an open-label, pilot, randomised trial. Lancet 2019; 393: 61-73. DOI: 10.1016/S0140-6736(18)32484-X

64. Gilstrap LG, Fonarow GC, Desai AS, Liang L, Matsouaka R, DeVore AD, Smith EE, Heidenreich P, Hernandez AF, Yancy CW, Bhatt DL. Initiation, continuation, or withdrawal of angiotensin-converting enzyme inhibitors/ angiotensin receptor blockers and outcomes in patients hospitalized with heart failure with reduced ejection fraction. J Am Heart Assoc 2017;6(2):e004675.DOI: 10.1161/JAHA.116.004675

65. Di Somma S. Importance of rapid and effective reduction of blood pressure in treating hypertension for the prevention of cardiovascular diseases: a lesson from the VALUE study. High Blood Press Cardiovasc
Prev 2005; 12: 135-40.doi: 10.2165/00151642-200512030-00004.

66. Zhang H, Penninger JM, Li Y, Zhong N, Slutsky AS. Angiotensin-converting enzyme 2 (ACE2) as a SARS-CoV-2 receptor: molecular mechanisms and potential therapeutic target. Intensive Care Med (2020) 46:586-590. DOI 10.1007/s00134-020-05985-9

\section{Citation:}

Vela Vásquez RS. Renin Angiotensin System and Coronavirus Disease 2019 (COVID-19): An updated review. Cardio Vasc Syst. 2020; 8:2.

http://dx.doi.org/10.7243/2052-4358-8-2 